\title{
FOUNDING ELECTIONS IN THE DEMOCRATIC REPUBLIC OF CONGO \\ A Highly Fragmented Party System
}

\author{
Patrick Vander Weyden \\ Dr Vander Weyden is Vice-President of the Institute of Political Sociology \\ and Methodology, Catholic University of Brussels \\ Vrijheidslaan 171081 Brussels \\ Tel: +32 241242.64 \\ patrick.vanderweyden@kubrussel.ac.be
}

\begin{abstract}
In this paper we analyse the embryonic party system in the Democratic Republic of Congo as a result of the legislative and provincial elections. Although a strong electoral system (with small district magnitudes) was implemented, the party system fragmentation at national as well as at provincial level is very high. As illustrated in this paper, strong electoral systems (small district magnitudes) generate different effects in emerging democracies from more traditional democracies. The main reason for this difference is the absence of structured political party organisations. A democratic system needs some fragmentation to function, but a highly fragmented system runs the risk of not functioning at all. Thus we plead for investment in structuring the party system by developing cross-district party organisations and stimulating collaboration and cooperation between the numerous existing parties and independent politicians.
\end{abstract}

\section{INTRODUCTION}

Organising elections in a country the size of Western Europe, with little infrastructure and few tarred roads, is an enormous task. According to the Global and All-Inclusive Agreement, ratified by a constitutional referendum, the elections in the Democratic Republic of Congo (DRC) were to be held by 30 June 2006 at the latest, but the deadline was extended to 30 July because of the exceptional difficulties involved in organising them. 
The Global Agreement entrusted the organisation of the elections to the Commission Electorale Independente (CEI), led by Reverend Apollinaire Malu Malu. Between June 2005 and February 2006 the CEI focused on voter registration. Despite many difficulties it managed to register more than 90 per cent of the estimated electorate (about 25,6-million voters), which can be considered a notable success. On 18-19 December 2005 in a Constitutional Referendum 83 per cent of voters approved the new Constitution, which was duly promulgated by President Joseph Kabila on 18 February 2006. Thereafter, the CEI began to organise the provincial, legislative and presidential elections for 30 July. It registered 33 candidates for the presidential election, and 267 parties and more than 9500 candidates for the parliamentary and provincial elections, of whom about 770 were independent candidates, not affiliated to a political party.

The high number of participating candidates and political parties is typical of founding elections in democratising countries. As Bogdanor (1990, p 288) states:

at a founding election, party identification is likely to be weak ... and public opinion highly volatile. It is probably not until there have been at least two further free elections held under normal conditions that one will be in a position to make meaningful generalizations about the electoral process.

Although founding elections are only a first step in a democratisation process they are important because they form the basis of an emerging party system. Between the founding and second elections political groups will split or different political parties (or independents) will merge and form new political parties. Elected candidates and political parties represented in parliament at the founding elections have an advantage over non-represented political groups and politicians. So describing and analysing the emerging party system at founding elections is an important academic activity to highlight potential future difficulties and opportunities. (Founding) elections take place within a set of electoral rules. Political scientists have done abundant research into the causal relation between electoral systems and party systems. If we look to the effects of electoral systems on the number of parties (as the main feature of a party system) the evidence that in first-past-the-post (FPTP) systems the party systems are less fragmented seems quite convincing (Lijphart 1994). Within proportional representation (PR) systems electoral formulas with the largest remainders cause more fragmentation than systems with the highest averages. For example, a Hare quota system with largest remainders (as used in the DRC) causes a more proportional result than the D'Hondt system (a system with highest averages, as used, for example, in Cambodia), keeping the district magnitude constant (Rae 1971). 
Apart from the impact of the electoral formula, research is paying increasing attention to the effect of the second dimension of electoral systems, namely the number of seats to be distributed, following Taagepera \& Shugart (Cox 1997; Gallagher 1991; Taagepera \& Shugart 1989). Empirical results show that the lower the number of districts, the smaller the number of parties.

The main problem with this empirical and theoretical research is that the main conclusions are based on traditional democracies. Although some research has been done into the consequences of electoral systems in new democracies (Birch 2005; Moser 1999; Reilly \& Reynolds 1999; Reynolds 1999, 2002), there are many gaps to be filled.

When emerging and traditional democracies are compared major differences are evident. The traditional conclusion that FPTP results in a two-party system or that a FPTP system has a strong reductive effect on the number of parties in the party system seems not to hold in new democracies. On the contrary, FPTP systems in new democracies often result in a highly-fragmented system (Birch 2005; Moser 1999). The main reason for this is the absence of well-organised political parties. According to Moser (1999):

Even if the conditions are favorable for the establishment of twocandidate races at district level, the projection of this bipartism to the national level is not assured. Rather it depends on the ability of parties to unite prominent elites in single nationwide party organizations. If this is not accomplished the two candidates produced in plurality elections at the district level may belong to a multitude of different parties across the country ... Most importantly, the lack of well-established political parties undermines the ability of voters and elites to behave strategically. Parties serve as the primary mechanism to channel and aggregate public opinion, while electoral systems are a secondary mechanism influencing the number of viable political parties ... In weak party systems, the absence of party identification leaves voters with no cues, other than the personal characteristics of candidates and patronage, as to how to cast their votes. Due to the transitory nature of party organizations in the most unstable new democracies, parties continually enter and leave the scene and provide no continuity between electoral periods. Such conditions provide little opportunity for voters to cultivate lasting preferences for one party or another, leaving most uncommitted.

An important point of discussion in research on the effects of electoral systems, and related to the above-mentioned differences between emerging and well 
established democracies is the level of analysis. Duverger's dependent variable, the number of parties, is a variable at national system level (Duverger 1951 [1976]). However, the mechanical as well as the psychological effects occur first and foremost at district level, where votes are converted into seats. It is at this level that strategic or non-strategic voting behaviour and strategic party elite behaviour in relation to the electoral system is particularly relevant.

Research in the line of Duverger has mainly focused on the national level by, for instance, analysing the relationship of average district magnitude to national party systems (Blais \& Carty 1991; Bogdanor \& Butler 1983; Coppedge 1997; Farrell 1997; Lijphart 1994; Taagepera \& Shugart 1989). Although theoretically the problem is acknowledged (Cox 1997; Leys 1959; Sartori 1976, 1994; Taagepera \& Shugart 1989) very few studies work with electoral district data (Cox 1997; Shugart 1985). Yet, by carrying out analyses at district level we gain a theoretically and methodologically more accurate insight into the mechanical functioning of electoral systems (electoral formula and district magnitude). Moreover, 'interfering' variables, which are beyond the scope of the definition of electoral systems but which can play a role when analyses are conducted at national level, are excluded. An example of such an 'interfering' variable is 'malapportionment'. Malapportionment occurs when geographical units (electoral districts) are allotted a share of seats not equal to their share of the population (Monroe 1994). That is why we believe that in the field of electoral studies and to understand better the mechanical and psychological effects in traditional as well as in emerging democracies the empirical analysis should start at district level.

The central hypothesis to be tested in this paper is whether a strong electoral system in an emerging (electoral) democracy results in a highly fragmented party system. Small district magnitudes (defined as the number of seats to be distributed in a district) and a high number of electoral districts can be considered characteristics of a strong electoral system. To test this hypothesis the paper consists of three parts. Firstly, we will explore the characteristics of the electoral system used during the 2006 legislative and provincial elections in the DRC. Secondly, we will describe in general the legislative and provincial electoral results and parties followed by a more mathematical description of the party system (in casu the number of parties) at national, provincial and district level. And finally we will explore the relationship between district magnitude (as a dimension of electoral systems) and the effective number of parties.

\section{THE ELECTORAL SYSTEM}

The electoral system is regulated by the Electoral Law of 9 March 2006 (Loi n06/ 006), which encompasses presidential, legislative, provincial, and local elections. 
The presidential elections are held by direct popular vote, with the country as one constituency (Art 100). If no candidate obtains more than 50 per cent of the vote in the first round a run-off election is held between the two leading candidates from the first round. The DRC president is elected for a five-year term and can be re-elected once (Art 101).

For the distribution of the 500 seats in the Congolese Parliament (Assemblée Nationale), the country is divided into 169 districts and two electoral formulae are used (Art 115). The district magnitude for 62 districts is one, with a FPTP system applied (Art 118, 1). For 107 electoral districts with a district magnitude of more than one, a proportional representation (PR) system - the Hare quota with largest remainders - is used (Artss 118, 2 and 119). For these 107 PR districts, the district magnitude ranges from 2 to 17, with an average of 4,1 and a median of 3. Taking into account all districts, the mean district magnitude is 2,94; the median magnitude is 2 . More than 75 per cent of the districts have a magnitude of less than or equal to 3 (see Table 1).

The same electoral formulae are used for the provincial elections. The district magnitude forms the same pattern, although the mean magnitude is a little higher $(3,28)$ and the median magnitude is 3 (see Table 1 ).

Table 1

District Magnitude (M), Parliamentary and Provincial Elections

\begin{tabular}{|c|c|c|c|c|}
\hline $\mathbf{M}$ & \multicolumn{2}{|c|}{ Parliamentary Elections } & \multicolumn{2}{c|}{ Provincal Elections } \\
\hline & $\%$ & Cumulative $\%$ & $\%$ & Cumulative $\%$ \\
\hline 1 & 36,6 & 36,6 & 18,2 & 18,2 \\
\hline 2 & 22,6 & 59,1 & 27,8 & 46,0 \\
\hline 3 & 17,1 & 76,2 & 18,2 & 64,2 \\
\hline 4 & 8,5 & 84,8 & 13,6 & 77,8 \\
\hline 5 & 4,3 & 89,0 & 8,5 & 86,4 \\
\hline 6 & 1,2 & 90,2 & 4,5 & 90,9 \\
\hline 7 & 1,8 & 92,1 & 5,7 & 96,6 \\
\hline 8 & 2,4 & 94,5 & 1,1 & 97,7 \\
\hline 9 & 1,2 & 95,7 & 0,6 & 98,3 \\
\hline 10 & 0,6 & 96,3 & & \\
\hline 11 & 1,2 & 97,6 & 0,6 & 98,9 \\
\hline 12 & & & 0,6 & 99,4 \\
\hline
\end{tabular}




\begin{tabular}{|l|c|c|c|c|}
\hline 13 & 0,6 & 98,2 & & \\
\hline 14 & 1,2 & 99,4 & 0,6 & 100 \\
\hline 15 & & & & \\
\hline 16 & & & & \\
\hline 17 & 0,6 & 100 & & \\
\hline Total & 100 & & 100 & \\
\hline Mean M & 2,94 & & 3,28 & \\
\hline Median M & 2,00 & & 3,00 & \\
\hline
\end{tabular}

Still, compared to other countries, the structure for the provincial elections is characterised by numerous very small districts. Thus we can conclude that the electoral system used in the DRC will cause strong mechanical effects. ${ }^{1}$

In addition to the electoral system and district magnitude it is important to mention that elections are conducted according to an open list system, allowing voters to vote for one candidate only. Candidates for the Assemblée Nationale can present themselves either as an independent candidate or as a candidate for a political party (Art 12). To determine which candidates obtain the seats won by their party, candidate votes are aggregated by party to calculate the number of seats for each party. Once this calculation has been made, seats are allocated to the candidate(s) with the highest number of votes for each party (Art 119).

\section{DATA COLLECTION}

For parliamentary as well as provincial elections the territory was divided into electoral districts. As our analysis is concentrated on the district level we collected our data at district level and in as much detail as possible. This meant including in our database the number of votes won by each party, regardless of the strength of the party.

We were able to download detailed provincial election results from the website of the Commission Electoral Indépendante (CEI)(http: / / www.cei-rdc.cd). Unfortunately, the data for the legislative elections were removed from the website of the electoral commission shortly after the elections. ${ }^{2}$

1 Mechanical effects can, for example, be measured by differences between vote proportions and seat proportions. The higher these differences the stronger the mechanical effects.

2 We made several applications (by phone, e-mail, and mail) to the Commission Electoral Indépendante to receive the detailed results but received no response. 
The only other source of data on the DRC elections is Adam Carr's election archive (http: / / psephos.adam-carr.net / ) but we were not able to check whether these data are correct, since they are not presented according to the existing constituencies and provinces. Furthermore, Adam Carr aggregated his data by grouping smaller parties (fewer than 10 seats at the national level). The lack of detailed election data has consequences for some of our calculations (see below).

\section{POLITICAL PARTIES AND CANDIDATES}

Political parties in Congo have three main weaknesses: absence of ideology, structural deficiencies generating internal instability, and the survival of ethnic mentalities. Moreover, parties are generally based on personalities and ethnic affiliations not on issues, and have strong regional ties.

The Parti du Peuple pour la Reconstruction et la Démocratie (PPRD), led by Joseph Kabila, has its support base mostly in Katanga and the Kivus. The PPRD's main programme was to rebuild the country and encourage Congolese nationalism. In addition, the Alliance pour la Majorité Présidentielle (AMP), a huge coalition of parties built around Kabila and the PPRD, was formed, with the aim of winning the presidency and securing a majority in Parliament. Kabila and his PPRD were generally seen as the favourites to win the presidential, parliamentary and provincial elections.

The main challenger to the PPRD was the Mouvement de Libération du Congo (MLC), a movement of former rebels led by Jean-Pierre Bemba; its stronghold is in Equateur province and it is closely linked to Uganda. Its presidential candidate was Bemba, a vice-president in the transitional government, who stood on a platform of promoting social justice and authentic Congolese nationalism.

The Rassemblement Congolais pour la Démocratie (RCD) also originated in a rebel movement. Its leader, Azarias Ruberwa, was, similarly, a vice-president in the transition government and the RCD's presidential candidate. The RCD is linked with Rwanda, and Ruberwa campaigned against corruption in Congo.

The fourth important party in Congolese politics is Parti Lumumbiste Unifié (Palu), the party centred on Antoine Gizenga. Having been active in Congolese politics since independence in 1960 Gizenga has been imprisoned several times and has lived in exile for almost 30 years (Paco/Unops 2006, p15). Palu has widespread support in Gizenga's home province, Bandundu, and in Kinshasa.

A remarkable candidate for the presidency was Nzanga Mobutu, son of the former dictator Joseph-Désiré Mobutu, and his party, Union des Démocrates Mobutistes (Udemo), which took part in the parliamentary elections. (Udemo won 9 seats, 8 of which were in Equator, and therefore does not feature in Table 1). 
Finally, there was the presidential candidacy of Oscar Kashala Lukumuenda, a cancer specialist living in the USA, with his Union Pour la Reconstruction du Congo (Urec), a coalition of 30 small parties. Tshisekedi's UDPS also played an important role in the elections - by boycotting them.

Since this paper is concerned with the development of the Congolese party system at national and provincial level we will explore the election results at these levels.

\section{ELECTION RESULTS}

According to the almost 1700 international observers present during the elections, they generally took place in a calm and free atmosphere and most of the electoral bureaus were well organised. The overall turnout was very high (estimated as between $70 \%$ and $90 \%$ ), except in the Kasaï provinces, where it was about $40 \%$ because of the UDPS boycott.

In Table 2 the distribution of seats in Parliament is given at provincial level, and shows only the parties that won at least 10 seats. The fact that no fewer than 132 lists (of which 63 were independent candidates) are represented in Parliament illustrates the level of fragmentation.

Kabila's PPRD, with 111 seats, was the clear winner of the parliamentary election. The main challenger, the MLC, finished second, with 64; and Palu finished third, with 34 seats.

Five other parties won 10 seats or more: MSR, Forces, RCD, Codeco and CDC. Another 61 parties won fewer than 10 seats, and are shown in the 'Others' column in the table.

The PPRD was the convincing winner in Province Orientale, Nord- and SudKivu, and Katanga. The MLC's strength was in Equateur and Ville de Kinshasa. The victory of Palu in Gizenga's home province, Bandundu, where it won 25 of its 34 seats, was remarkable.

If we look to the provincial results (Table 3), we see a comparable picture. With 124 seats, the PPRD was also the clear winner of the provincial elections. As in the parliamentary elections the MLC finished second, with 89 seats. Palu lost its third position to the RCD. In both elections the high number of the category 'others' and 'independents' illustrates the high fragmentation of the party system at national and provincial level. That is why it was difficult to form a national government after the elections because more than 50 political groups were involved in a parliamentary majority coalition. It is worth mentioning that the fragmentation is even higher than illustrated by the numbers. Some electoral lists consist of a motley collection of smaller political groups, which makes the political situation even more complex than the numbers suggest. 


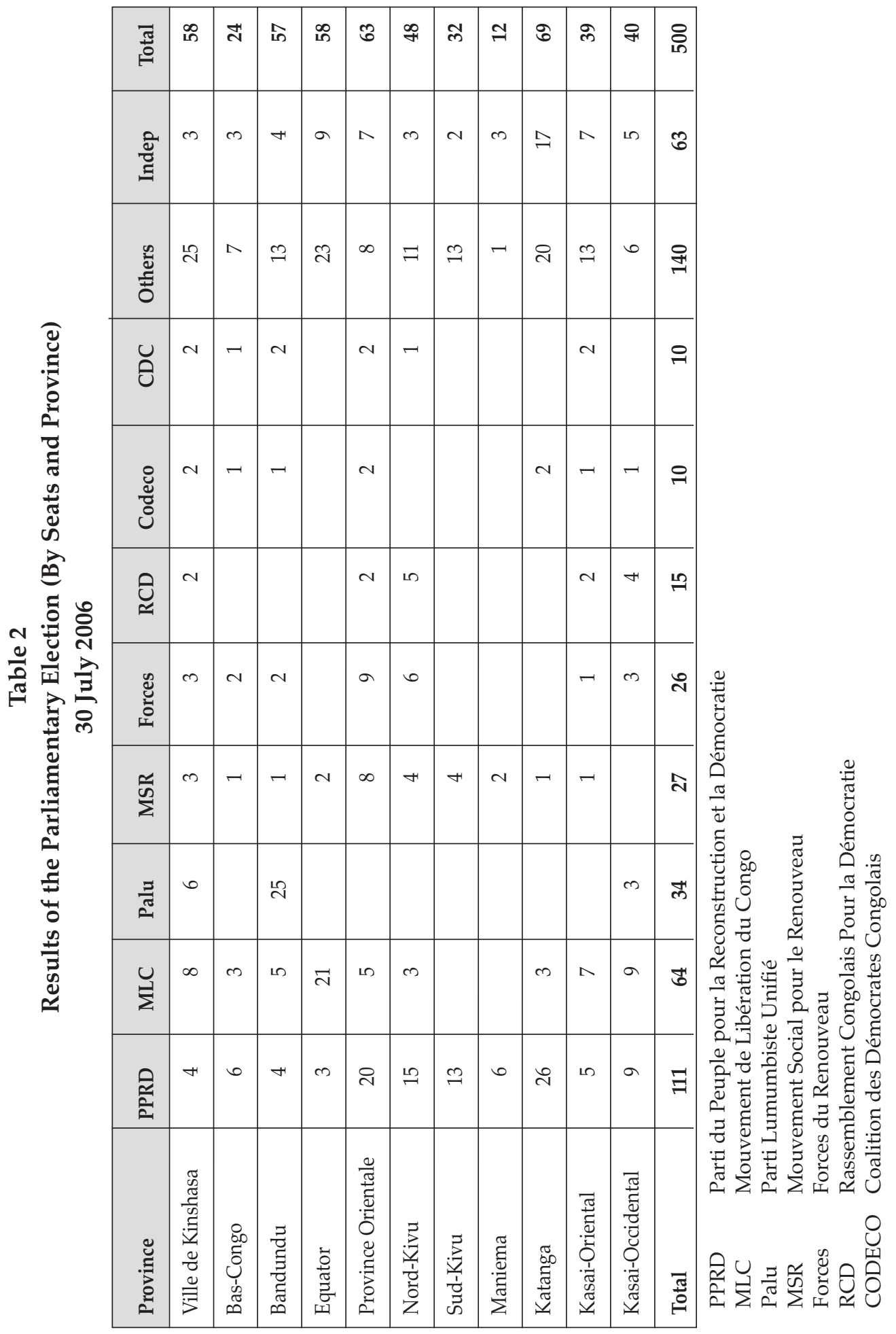




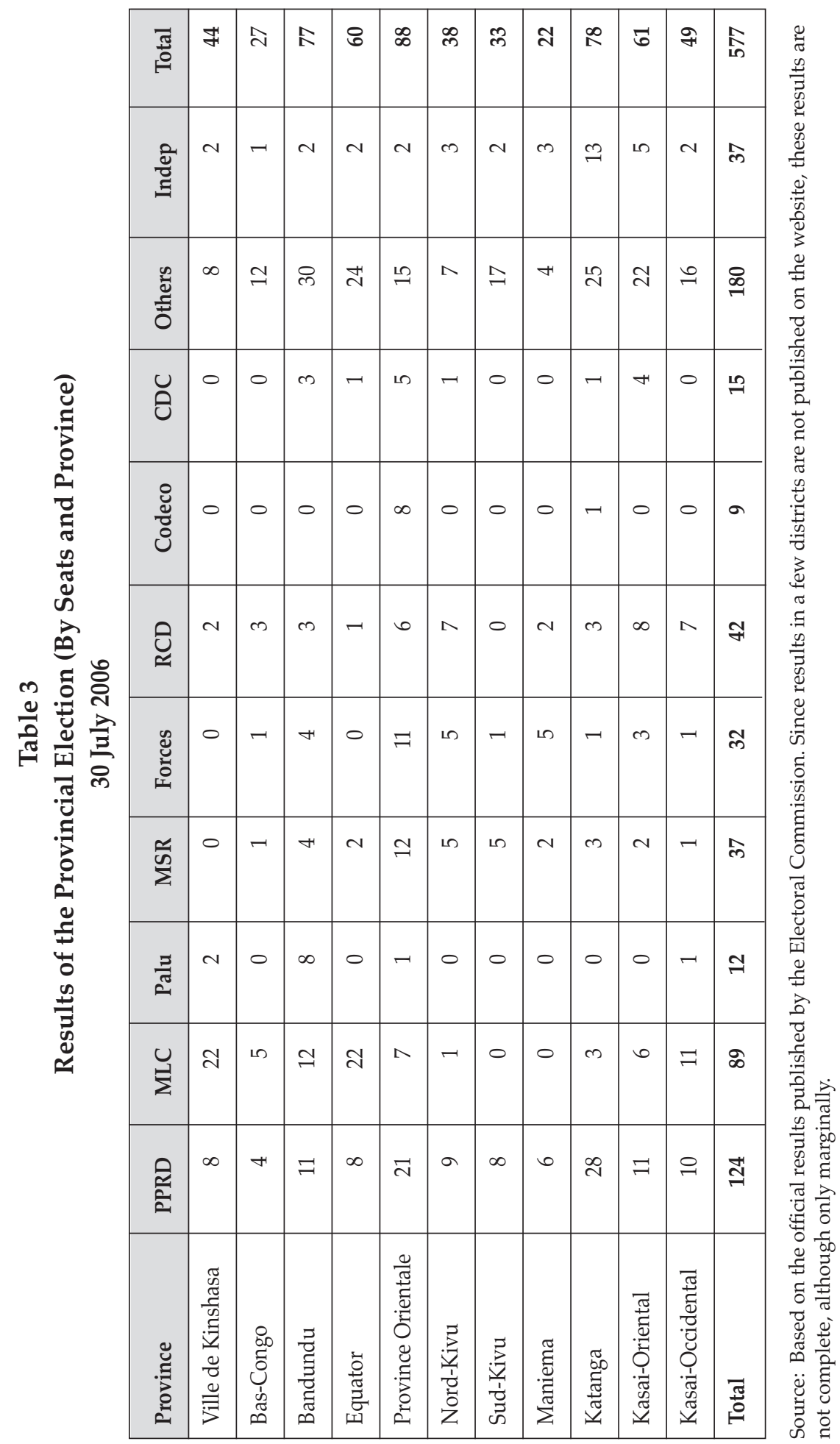




\section{THE PARTY SYSTEM: THE NUMBER OF PARTIES}

In recent years, academic descriptions of party systems have emphasised the calculation of the relative share of the national vote (Laakso \& Taagepera 1979), following Rae's fractionalisation index (Rae 1971). Especially in comparative studies of electoral system effects on party systems (see, eg, Taagepera 1989; Lijphart 1994; Cox 1997) but also in studies describing and explaining party systems in specific cases (Chhibber \& Kollman 1998; Moser 1999; Olsen 1998), the 'effective number of parties' is used as a standard measure. The effective number is calculated as follows:

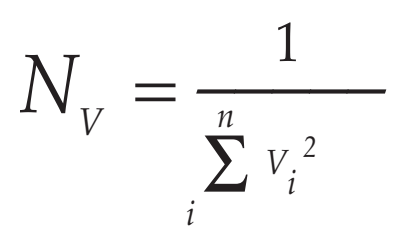

Vi represents party i's relative share of national votes. Since we will also do our calculations at district level we will refer to the 'effective number of electoral district parties' with the term DNV. Basically, this method of calculation boils down to weighing parties according to their own relative electoral importance. The same mathematical formula is used to calculate the effective number of parliamentary (or provincial council) parties (effective number of parties having seats in the parliament or provincial councils). The terms NS and DNS refer to the effective national / provincial parliamentary or provincial council parties and the effective district provincial parliamentary or provincial council parties respectively.

The effective number of national parliamentary parties (NS) is 10,5, a very high number compared to other countries. Since we grouped the independent candidates together, this number hides a more complex political landscape. Sixtythree of the 500 members of Parliament are independent, which means they constitute 12,3 per cent of all elected members. If we consider all these independent candidates as separate parties the number of parties rises to 12,48 .

As mentioned above, the data for the legislative elections were removed from the website of the Electoral Commission shortly after the elections, so we were not able to calculate the effective number of parliamentary and electoral parties at district level.

For the provincial elections we aggregated the district level data to the 11 provinces. If we look at Table 4 we find a highly fragmented electoral arena with an effective number of electoral parties as high as 22 in Kinshasa! Only three of the 11 provinces have fewer than 10 parties. On the other hand, the reductive 
effect of the electoral systems is quite high (see Table 5). Only two provinces have more than 10 effective provincial council parties. But the fragmentation at council level still remains very high.

All these factors (high electoral fragmentation, strong reductive effect and a lower number of provincial council parties) create strong incentives for party elites to search for cooperation in the near future. In our opinion one of the main efforts to be made in the following years will be the regrouping of numerous political actors in the embryonic Congolese party system. If party elites are unable to regroup the system will remain highly fragmented and voting will remain unstructured. A more structured party system is necessary for the development of a democratic political system. This means, too, that political parties and groups must develop a working relationship across the different districts and provinces. If the international community wants to assist the development of the democratisation process in the DRC it must invest in structuring the party system.

Table 4

Effective Number of Parties: Provincial Election, 11 Old Provinces

\begin{tabular}{|l|c|c|}
\hline Old provinces & $\begin{array}{c}\text { Effective number of } \\
\text { elective provincial parties }\end{array}$ & $\begin{array}{c}\text { Effective number of } \\
\text { provincial council parties }\end{array}$ \\
\hline Bandundu & 16,63 & 12,87 \\
\hline Bas-Congo & 16,12 & 8,78 \\
\hline Equateur & 8,86 & 5,68 \\
\hline Kasai Occidental & 13,03 & 8,03 \\
\hline Kasai Oriental & 18,56 & 12,04 \\
\hline Katanga & 8,57 & 5,40 \\
\hline Kinshasa & 22,23 & 3,37 \\
\hline Maniema & 9,27 & 7,08 \\
\hline Nord-Kivu & 11,57 & 7,74 \\
\hline Province Orientale & 11,00 & 8,57 \\
\hline Sud-Kivu & 18,11 & \\
\hline
\end{tabular}




\section{Table 5}

Provincial Election, Mean M and Reductive Effect

\begin{tabular}{|l|c|c|}
\hline Old provinces & Mean M & Reductive effect \\
\hline Kinshasa & 1,83 & 18,86 \\
\hline Bas-Congo & 2,25 & 7,34 \\
\hline Maniema & 2,75 & 3,37 \\
\hline Equateur & 3,00 & 3,18 \\
\hline Kasai Oriental & 3,39 & 6,52 \\
\hline Province Orientale & 3,52 & 2,26 \\
\hline Sud-Kivu & 3,67 & 3,24 \\
\hline Bandundu & 3,85 & 3,76 \\
\hline Kasai Occidental & 4,08 & 5,00 \\
\hline Katanga & 4,11 & 3,17 \\
\hline Nord-Kivu & 4,22 & 4,49 \\
\hline
\end{tabular}

The argument for or the appeal of investing in regrouping the party system and mobilising party elites to develop stronger party organisation is even stronger if the electoral system is kept constant. As mentioned above, a large number of districts with low magnitude tends to increase the number of parties in emerging democracies because of the absence of strong party organisations. But because of the numerous districts with small magnitudes and the weak organisational structure of parties across districts, the number of parties at provincial and national level is one of the highest in the world.

According to Benjamin Reilly (2006, p 816) there are at least four distinct approaches to encourage the development of centrist, aggregative (and multiethnic) political parties:

1. Constrain the development of ethnic parties by cross-national party formation rules which require parties to demonstrate a broad organisational base.

2. Design electoral rules to reshape the party system.

3. Strengthen parties from the top down via measures to build greater internal party discipline and organisational capacity.

4. International interventions to influence party systems in post-conflict democracies. 
Perhaps it is too late for the international community to intervene directly in the internal political dynamics of the DRC but it is still possible to encourage political leaders and parties to take great pains over the first three strategies suggested by Reilly. It is worth examining whether it is useful to allow independent candidates to run for the elections.

Other measures, like a proven cross-provincial and national organisational base (eg, a minimum number of members in at least half the provinces), an electoral threshold (eg, $5 \%$ nationwide and in at least one-third of the provinces), a positive (financial) incentive for parliamentary parties with at least 20 seats and regulations for elected members under one party label to stay within that party during the legislative period would be important steps in structuring the party system in the long run.

\section{CONCLUSION}

Although a strong electoral system (with small district magnitudes) was implemented in the legislative as well as in the provincial elections in the DRC, the fragmentation of the party system at national as well as at provincial level is very high.

As illustrated in this paper strong electoral systems (small district magnitudes) generate different effects in emerging democracies compared to more traditional democracies. The main reason for this is the absence of structured political party organisations. A democratic system requires some fragmentation to function, but a highly fragmented system runs the risk of not functioning at all. That is why we plead for investment in structuring the party system by development of cross-district party organisations and collaboration and cooperation between the numerous existing parties and independent politicians.

A more structured party system is necessary for the development of a democratic political system. This means, too, that political parties and groups must develop a working relationship across the different districts and provinces.

If the international community wishes to assist the development of democratisation in the DRC it must invest in structuring the party system. At least, parties and party elites must be persuaded to introduce electoral thresholds. Parties should meet minimal party organisational requirements in order to participate in elections. 


\section{- REFERENCES}

Birch, S. 2005. 'Single-Member District Electoral Systems and Democratic Transition'. Electoral Studies 24.

Blais, A \& R K Carty. 1991. ‘The Pscyhological Impact of Electoral Laws: Measuring Duverger's Elusive Factor'. British Journal of Political Science 2(1).

Bogdanor, V. 1990. 'Founding Elections and Regime Change'. Electoral Studies 94.

— \& D Butler (eds). 1983. Democracy and Elections: Electoral Systems and Their Political Consequences. Cambridge: Cambridge University Press.

Chhibber, P. \& K Kollman. 1998. 'Party Aggregation and the Number of Parties in India and the United States'. American Political Science Review 922.

Coppedge, M. 1997. 'District Magnitude, Economic Performance, and Party-System Fragmentation in Five Latin American Countries'. Comparative Political Studies 302.

Cox, G W. 1997. Making Votes Count. Cambridge: Cambridge University Press.

Duverger, M. 1951 [1976]. Les partis politiques. Paris: Librairie Armand Colin.

Farrell, D M. 1997. Comparing Electoral Systems. London: Prentice Hall.

Gallagher, M. 1991. 'Proportionality, Disproportionality and Electoral Systems'. Electoral Studies 101.

Laakso, M \& R Taagepera. 1979. 'The Effective Number of Parties: A Measure with Application to West Europe'. Comparative Political Studies 12.

Leys, C. 1959. 'Models, Theories and the Theory of Political Parties'. Political Studies 72.

Lijphart, A. 1994. Electoral Systems and Party Systems. A Study of Twenty-Seven Democracies, 1945-1990. Oxford: Oxford University Press.

Monroe, B L. 1994. 'Disproportionality and Malaportionment: Measuring Electoral Inequity'. Electoral Studies 132.

Moser, R G. 1999. 'Electoral Systems and the Number of Parties in Postcommunist States'. World Politics 51.

Olsen, D M. 1998. 'Party Formation and Party System Consolidation in the New Democracies of Central Europe'. In H Hofferbert (ed). Parties and Democracy. Oxford: Blackwell Publishers.

Paco/Unops. International Observer Handbook Presidential and Legislative Elections DRCongo. Kinshasa: Paco/UNOPS.

Rae, D W. 1971. The Political Consequences of Electoral Laws. New Haven \& London: Yale University Press.

Reilly, B. 2006. 'Political Engineering and Party Politics in Conflict-Prone Societies'. Democratization 135.

\& A Reynolds. 1999. Electoral Systems and Conflict in Divided Societies. Washington, DC: National Academy Press. 
Reynolds, A. 1999. Electoral Systems and Democratization in Southern Africa. Oxford: Oxford University Press.

--_--. 2002. The Architecture of Democracy: Constitutional Design, Conflict Management, and Democracy. Oxford: Oxford University Press.

Sartori, G. 1976. Parties and Party Systems. A Framework of Analysis. Cambridge: Cambridge University Press.

—. 1994. Comparative Constitutional Engineering. London: Macmillan.

Shugart, MS. 1985. 'The Two Effects of District Magnitude: Venezuela as a Crucial Experiment'. European Journal of Political Research 13.

Taagepera, R \& M S Shugart. 1989. Seats and Votes. The Effects and Determinants of Electoral Systems. New Haven \& London: Yale University Press. 